This article was downloaded by: [163.47.14.55]

On: 09 June 2015, At: 08:20

Publisher: Taylor \& Francis

Informa Ltd Registered in England and Wales Registered Number: 1072954 Registered office: Mortimer House, 37-41 Mortimer Street, London W1T 3J H, UK

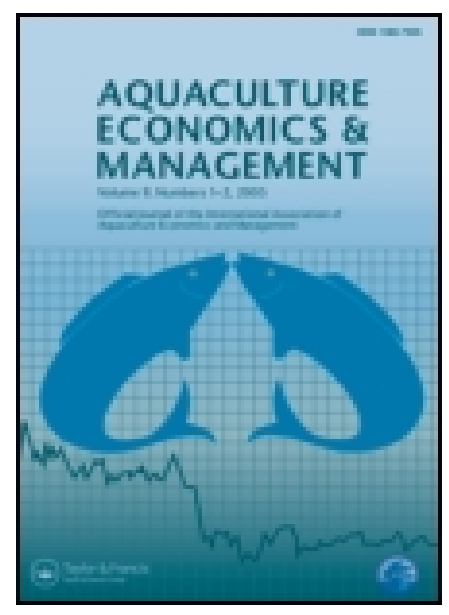

CrossMark

Click for updates

\section{Aquaculture Economics \& Management}

Publication details, including instructions for authors and subscription information:

http:// www.tandfonline.com/loi/ uagm20

\section{The Economics of Kappaphycus Seaweed Cultivation in Developing Countries: A Comparative Analysis of Farming Systems}

Diego Valderrama ${ }^{a}$, J unning $\mathrm{Cai}^{\mathrm{b}}{ }^{\mathrm{b}}$, Nathanael Hishamunda ${ }^{\mathrm{b}}$, Neil Ridler $^{c}$, lain C. Neish ${ }^{d}$, Anicia Q. Hurtado ${ }^{e}$, Flower E. Msuya ${ }^{f}$, M. Krishnan $^{g}$, R. Narayanakumarh ${ }^{h}$, Mechthild Kronen', Daniel Robledo ${ }^{j}$, Eucario Gasca-Leyva ${ }^{j} \&$ J ulia Fragak

${ }^{a}$ Food and Resource Economics Department, University of Florida, Gainesville, Florida, USA

${ }^{\mathrm{b}}$ Fisheries and Aquaculture Department, Food and Agriculture Organization of the United Nations, Rome, Italy

${ }^{\mathrm{c}}$ Consultant, Food and Agriculture Organization of the United Nations, New Brunswick, Canada

${ }^{d}$ C.V. Evadian, Makassar, Indonesia

${ }^{\mathrm{e}}$ Integrated Services for the Development of Aquaculture and Fisheries, Iloilo City, Philippines

${ }^{f}$ Seaweed Cluster Initiative, Institute of Marine Sciences, University of Dar es Salaam, Zanzibar, Tanzania

${ }^{g}$ Social Sciences Division, Central Institute of Fisheries Education, Mumbai, India

${ }^{\mathrm{h}}$ Socioeconomic Evaluation and Technology Transfer Division, Central Marine Fisheries Research Institute, Kochi, India

' Office of the European Commission for the Pacific Overseas Countries and Territories, Noumea, New Caledonia

${ }^{j}$ Marine Resources Department, Centro de Investigación y de Estudios Avanzados del Instituto Politécnico Nacional (CINVESTAV), Mérida, Mexico

${ }^{\mathrm{k}}$ Human Ecology Department, Centro de Investigación y de Estudios Avanzados del Instituto Politécnico Nacional (CINVESTAV), Mérida, Mexico

Published online: 11 May 2015.

To cite this article: Diego Valderrama, J unning Cai, Nathanael Hishamunda, Neil Ridler, lain C. Neish, Anicia Q. Hurtado, Flower E. Msuya, M. Krishnan, R. Narayanakumar, Mechthild Kronen, Daniel Robledo, Eucario Gasca-Leyva \& J ulia Fraga (2015) The Economics of Kappaphycus Seaweed Cultivation in Developing Countries: A Comparative Analysis of Farming Systems, Aquaculture Economics \& Management, 19:2, 251-277, DOI: 10.1080/ 13657305.2015.1024348 


\section{PLEASE SCROLL DOWN FOR ARTICLE}

Taylor \& Francis makes every effort to ensure the accuracy of all the information (the "Content") contained in the publications on our platform. However, Taylor \& Francis, our agents, and our licensors make no representations or warranties whatsoever as to the accuracy, completeness, or suitability for any purpose of the Content. Any opinions and views expressed in this publication are the opinions and views of the authors, and are not the views of or endorsed by Taylor \& Francis. The accuracy of the Content should not be relied upon and should be independently verified with primary sources of information. Taylor and Francis shall not be liable for any losses, actions, claims, proceedings, demands, costs, expenses, damages, and other liabilities whatsoever or howsoever caused arising directly or indirectly in connection with, in relation to or arising out of the use of the Content.

This article may be used for research, teaching, and private study purposes. Any substantial or systematic reproduction, redistribution, reselling, loan, sub-licensing, systematic supply, or distribution in any form to anyone is expressly forbidden. Terms \& Conditions of access and use can be found at http://www.tandfonline.com/page/termsand-conditions 


\title{
THE ECONOMICS OF KAPPAPHYCUS SEAWEED CULTIVATION IN DEVELOPING COUNTRIES: A COMPARATIVE ANALYSIS OF FARMING SYSTEMS
}

\author{
Diego Valderrama, ${ }^{1}$ Junning Cai, ${ }^{2}$ Nathanael Hishamunda, ${ }^{2}$ Neil Ridler, $^{3}$ \\ lain C. Neish, ${ }^{4}$ Anicia Q. Hurtado, ${ }^{5}$ Flower E. Msuya, ${ }^{6}$ M. Krishnan, ${ }^{7}$ \\ R. Narayanakumar, ${ }^{8}$ Mechthild Kronen, ${ }^{9}$ Daniel Robledo, ${ }^{10}$ \\ Eucario Gasca-Leyva, ${ }^{10}$ and Julia Fraga ${ }^{11}$ \\ ${ }^{1}$ Food and Resource Economics Department, University of Florida, Gainesville, Florida, USA \\ ${ }^{2}$ Fisheries and Aquaculture Department, Food and Agriculture Organization of the United \\ Nations, Rome, Italy \\ ${ }^{3}$ Consultant, Food and Agriculture Organization of the United Nations, New Brunswick, \\ Canada \\ ${ }^{4}$ C.V. Evadian, Makassar, Indonesia \\ ${ }^{5}$ Integrated Services for the Development of Aquaculture and Fisheries, Iloilo City, Philippines \\ ${ }^{6}$ Seaweed Cluster Initiative, Institute of Marine Sciences, University of Dar es Salaam, \\ Zanzibar, Tanzania \\ ${ }^{7}$ Social Sciences Division, Central Institute of Fisheries Education, Mumbai, India \\ ${ }^{8}$ Socioeconomic Evaluation and Technology Transfer Division, Central Marine Fisheries \\ Research Institute, Kochi, India \\ ${ }^{9}$ Office of the European Commission for the Pacific Overseas Countries and Territories, \\ Noumea, New Caledonia \\ ${ }^{10}$ Marine Resources Department, Centro de Investigación y de Estudios Avanzados del \\ Instituto Politécnico Nacional (CINVESTAV), Mérida, Mexico \\ ${ }^{11}$ Human Ecology Department, Centro de Investigación y de Estudios Avanzados del Instituto \\ Politécnico Nacional (CINVESTAV), Mérida, Mexico
}

The farming of the red seaweed Kappaphycus alvarezii and related species as raw material for the hydrocolloid carrageenan rapidly spread from the Philippines in the late 1960s to Indonesia, Tanzania, and other tropical countries around the world. Although numerous studies have documented positive socioeconomic impacts for seaweed farming, factors such as diseases and distance to export markets have led to an uneven development of the industry. Using standard budgeting techniques, this study adapted production and market data from a FAO-led global review of seaweed farming to develop comparative enterprise budgets for eight farming systems in six countries (Indonesia, the Philippines, Tanzania, India, Solomon Islands, and Mexico).

Address correspondence to Diego Valderrama, Food and Resource Department, University of Florida, P.O. Box 110240, Gainesville, FL 32611-0240, USA. E-mail: dvalderrama@ufl.edu 


\begin{abstract}
Although the basic technology package is the same across countries, the study revealed large differences in the economic performance of systems due to wide variations in farm prices and the scale of operations. Although seaweed farming is a suitable activity for small-scale producers, a minimum of 2,000 m of cultures lines are still necessary to ensure adequate economic returns. Greater farming plots may be needed if farm prices are well below the average farm prices paid in Indonesia and the Philippines. Policy recommendations are made to improve the economic potential of underperforming systems.
\end{abstract}

Keywords Kappaphycus alvarezii, production economics, seaweed

\title{
INTRODUCTION
}

Seaweeds are harvested throughout the world (either collected from the wild or cultivated in farms) and used in a large number of applications, including food for human consumption or as a source of hydrocolloids processed into food additives, pet food, feeds, fertilizers, biofuel, cosmetics and medicines, among others (McHugh, 2003). The growing commercial importance of two hydrocolloids, in particular agar and carrageenan, has driven substantial development of red seaweed cultivation around the world in the last two decades. ${ }^{1}$ Major red seaweed species under cultivation include Kappaphycus and Eucheuma, which are primary raw materials for carrageenan, and Gracilaria, the primary raw material for agar. ${ }^{2}$

Carrageenan is a gelling agent used as an emulsifier, a binder, or for suspension and stabilization in a remarkably wide range of products in the food processing, pharmaceutical and cosmetic industries (Bixler \& Porse, 2011). Demand for carrageenan rose substantially after World War II, with supplies limited by the availability of natural stocks of Chondrus crispus (Irish moss) from Canada, Ireland, Portugal, Spain and France and Gigartina/Iridaea from South America and Southern Europe (Trono, 1993). By the late 1960s, dwindling wild stocks drove producers to scout the world coastlines in order to diversify seaweed supplies; at the same time, seaweed ecology research unveiled the potential of cultivation as an alternative source of raw material supply (Naylor, 1976). These efforts finally met success in southern Philippines, where native Eucheuma seaweeds were found to produce high-quality carrageenan and ecological conditions made cultivation possible. The first seaweed farm was established jointly in 1969 by U.S.-based Marine Colloids, Inc. (MCI) and University of Hawaii Professor Maxwell Doty in the southern Philippines province of Tawi-Tawi (Trono, 1990). The two species originally cultivated were named Eucheuma cottonii and Eucheuma spinosum, commercially referred to as "cottonii" and "spinosum." However, botanists renamed Eucheuma cottonii as Kappaphycus alvarezii while Eucheuma spinosum is now Eucheuma denticulatum. The commercial names cottonii and spinosum are still in use, nevertheless (McHugh, 2003). 
Production of Kappaphycus and Eucheuma spread rapidly in the Philippines, which soon displaced Canada as the top supplier of carrageenan seaweeds. The lower cost of labor in the Philippines further incentivized companies to source supplies from the Asian nation. Although the same corporations that dominated the Canadian market tried to control production in the Philippines through plantation-style seaweed farms, they soon realized they could not compete with small, family-run farms. The reasons were two-fold: 1) the labor for seaweed cultivation must be highly flexible to work on the cyclical time scales of tides and the moon, making it difficult to pay workers stable wages; and 2) seaweed farming has low capital and technological requirements for entry (Blanchetti-Revelli, 1995).

The success of carrageenan seaweed aquaculture in the Philippines was rapidly replicated in Indonesia. Kappaphycus alvarezii and E. denticulatum have also been introduced to more than 20 countries over the past 35 years to spur farm development around the world (Bindu \& Levine, 2011); however, significant production for export markets has only been achieved in Tanzania, Malaysia, and more recently Vietnam. Industry analysts estimate that global aquaculture production had reached 183 thousand tons (dry weight) by 2009 (Bixler \& Porse, 2011), with around 90\% of total output coming from Indonesia and the Philippines. Hampered by disease outbreaks and political unrest in farming areas, the Philippines were surpassed by Indonesia as the leading producer of carrageenan seaweeds around 2008. According to UN export statistics, Indonesia's output continues to increase at a faster rate than other countries (UN COMTRADE, 2014), reaching around 230 thousand tons of dry seaweed by 2013 (I. Neish, personal communication, June 17, 2014). By comparison, Tanzania (the largest producer outside Asia) produced less than 16 thousand tons (mostly E. denticulatum) in 2012 (FAO, 2014).

From its beginnings, carrageenan seaweed farming proved to be a profitable commercial proposition for many coastal communities. For example, Naylor (1976) demonstrated that for plots of approximately one hectare, net income from seaweed farming was five to six times the minimum average wage of an agricultural worker. Recognizing its potential to improve the socioeconomic conditions of marginalized coastal populations, international development agencies began promoting seaweed farming in Indonesia and neighboring countries since the 1980s (Trono et al., 1980). Seaweed farming is a relatively simple technology requiring low initial capital investment; in addition, with growout cycles as short as six weeks and favorable prices, it provides a rapid and high return on investment.

A number of studies have corroborated the positive socioeconomic impacts of seaweed farming in countries as diverse as the Philippines, Indonesia, Tanzania, India, Vietnam and the Pacific Islands (Arnold, 
2008; Bindu, 2011; Msuya, 2006; My, 2011; Namudu \& Pickering, 2006; Pettersson-Löfquist, 1995; Sievanen et al., 2005; Zamroni \& Yamao, 2011). Although carrageenophytes are not a direct source of food, their culture has been shown to increase food security in farming villages because their revenue-earning potential is greater than that of alternative agricultural enterprises (Beveridge et al., 2010; Espaldon et al., 2010; Gupta, 2010). Many of these communities lack sufficient infrastructure (e.g., hatcheries, feed mills, extension services) to support other forms of aquaculture. Facing declining landings from capture fisheries, seaweed farming represent the most efficient and sustainable use of marine resources in these communities.

Despite its many advantages, seaweed farming can also be a challenging activity. In addition to disease outbreaks, predation by herbivorous fish and infrastructure damages resulting from tropical storms, farmers also have to deal with volatility in seaweed prices. Seaweed farming is particularly prone to boom-and-bust cycles given the large number of small-scale price-takers in the industry. Price volatility is further compounded by the absence of relevant, reliable and timely production statistics and market intelligence. In contrast to agricultural commodities such as coffee, copra or tea, there are no organized markets to provide benchmarking international prices for seaweed (Tinne et al., 2006).

Seaweed farmers, traders, and processors frequently make decisions based on speculations or misinformation, resulting in market fluctuations. A recent and dramatic example was the "seaweed price bubble" of 2008, when prices reached exorbitant levels fueled by apparent increases in demand from Chinese processors, with prices collapsing in the course of a few months. In Indonesia, for example, $K$. alvarezii prices more than tripled, from about USD 0.60 to as much as USD 1.80 per $\mathrm{kg}$ of dry seaweed. Given the sudden price increase, many farmers rushed to harvest immature or low-quality seaweed, flooding the market and precipitating the subsequent price crash (Barta, 2008).

Given the absence of a world market price and the fact that most seaweed is marketed through direct bilateral contracts (suppliers/ producers and processors/users), substantial differentials arise in the prices farmers receive depending on where the "farm gate" is located (Tinne et al., 2006). As a result, farmers in Philippines and Indonesia receive on average higher prices (normally between USD 0.60 and USD $1.40 / \mathrm{kg}$ ) than farmers in more remote locations such as Tanzania and the Pacific Islands (less than USD $0.50 / \mathrm{kg}$ ) due to the former countries' improved logistical capabilities and proximity to processing centers. The oligopsonistic nature of the industry (whereby a large number of raw material producers supply relatively few processors ${ }^{3}$ ) also puts farmers in Africa and the Pacific Islands at a disadvantage, giving them little market power to negotiate higher 
prices. Rising fuel costs for shipping have also reduced the margins of exporters, and therefore the farm gate prices they can offer.

Along with other factors such as farm productivity and economies of scale, differences in farm prices go a long way towards explaining why carrageenan seaweed farming seems to have a higher potential in Asian countries (Indonesia, Philippines) as compared to African and Pacific Island nations. Given the positive results achieved in eastern Indonesia over the last decade, the Indonesian government has embraced the industry as a key driver of economic development and has set ambitious production targets for the next few years (The Economist, 2013). In contrast, production in African countries is either stable or declining as farm profit margins shrink due to the spread of seaweed die-offs and the impact of lower prices (BBC News, 2014; Msuya, 2011a).

Given this backdrop, the goal of this article is to develop a comparative analysis of the production economics of carrageenan seaweed farming to better understand the differences in performance of production systems across world farming regions. The comparative analysis is based on eight farming systems in six developing countries (Indonesia, Philippines, Tanzania, India, Solomon Islands, and Mexico) selected from a recent FAO global review on the socioeconomic impacts of carrageenan seaweed farming (Valderrama et al., 2013). The systems were specifically selected in order to facilitate comparisons of farming technologies, cost structures and market conditions across countries. The primary objective of this analysis is to highlight and contrast those factors leading to improved performance of the Indonesian and Philippine systems. Another objective is to identify specific strategies to improve the profitability of farming systems in those countries farther away from export markets (i.e., Tanzania and Solomon Islands).

The article is organized as follows: the following section provides a brief description of the farming systems selected for the analysis; subsequently, investment costs for each production system are detailed in separate tables. Next, comparative enterprise budgets are developed to contrast the economic performance of the different systems. Finally, the article discusses the policy implications of the analysis and outlines recommendations to enhance the potential of seaweed farming as an economic development strategy for coastal communities.

\section{THE FARMING SYSTEMS}

The FAO review examined 23 case studies of carrageenan seaweed farming production in six developing countries: Indonesia, Philippines, Tanzania, India (Tamil Nadu), Solomon Islands and Mexico (Yucatan 
Peninsula). The study covered countries with established commercial production (Indonesia, Philippines, Tanzania) and with nascent farming sectors (India, Solomon Islands). Although no commercial aquaculture production is currently taking place in Mexico, the corresponding case studies updated the outcomes of experimental trials led by an academic institution in the community of Dzilam de Bravo (Yucatan) in the early 2000s (Muñoz et al., 2004). Despite the lack of commercial production, there continues to be an interest in the tropical Gulf of Mexico as a promising area for Kappaphycus farming development in Latin America (Hayashi et al., 2014). Along with Argentina, Brazil, and Venezuela, Mexico offers the best prospects for the development of seaweed-based industries in the Western Hemisphere (McHugh, 2002), which further motivated the inclusion of Mexican-based case studies.

All economic models reflect production and market conditions prevailing in 2009 and assume that seaweed farming is the primary occupation of participating households (Valderrama et al., 2013). Local currency values in all cases were converted to USD using 2009 exchange rates (Feenstra et al., 2013).

The farming technologies in the case studies are variants of the two most popular cultivation methods: the fixed, off-bottom line and the floating lines techniques. In the off-bottom method, monofilament nylon lines or polypropylene ropes are stretched (usually $1 \mathrm{~m}$ apart) between wooden stakes pounded into the substrate. Small pieces of seaweed $(50-100 \mathrm{~g})$ are then tied to the lines (Figure 1a). If the site is suitable and proper maintenance is provided, seaweed should reach 10 times its original size in sixeight weeks, when it can be harvested. The seaweed is then sun dried away from sand and dirt, then packed into bales ready for shipping. The floating lines method is suitable in protected areas where water current is weak or the water is too deep for fixed bottom lines. Normally, a floating construction or raft (typically a $3 \times 3 \mathrm{~m}$ square timber frame with polypropylene ropes stretched parallel in one direction between the timbers) is used to suspend the seaweed about $50-\mathrm{cm}$ below the surface. The seedlings are tied to the ropes and the raft is anchored to the bottom. Plastic bottles attached to the lines can also be used as floatation devices instead of a wooden raft (Figure 1b). The off-bottom line method allows easier access since the farmer can walk around the lines at low tide, but the floating lines have the advantage of being easily moved to another position if necessary, and removed from the water altogether in bad weather (McHugh, 2003).

To make meaningful comparisons across case studies and facilitate understanding of the different farming contexts, eight representative systems were selected for the comparative analysis. Because these systems varied in scale and farming method, standardized metrics such as productivity per $\mathrm{m}$ of line and production cost per $\mathrm{kg}$ of dry seaweed were 

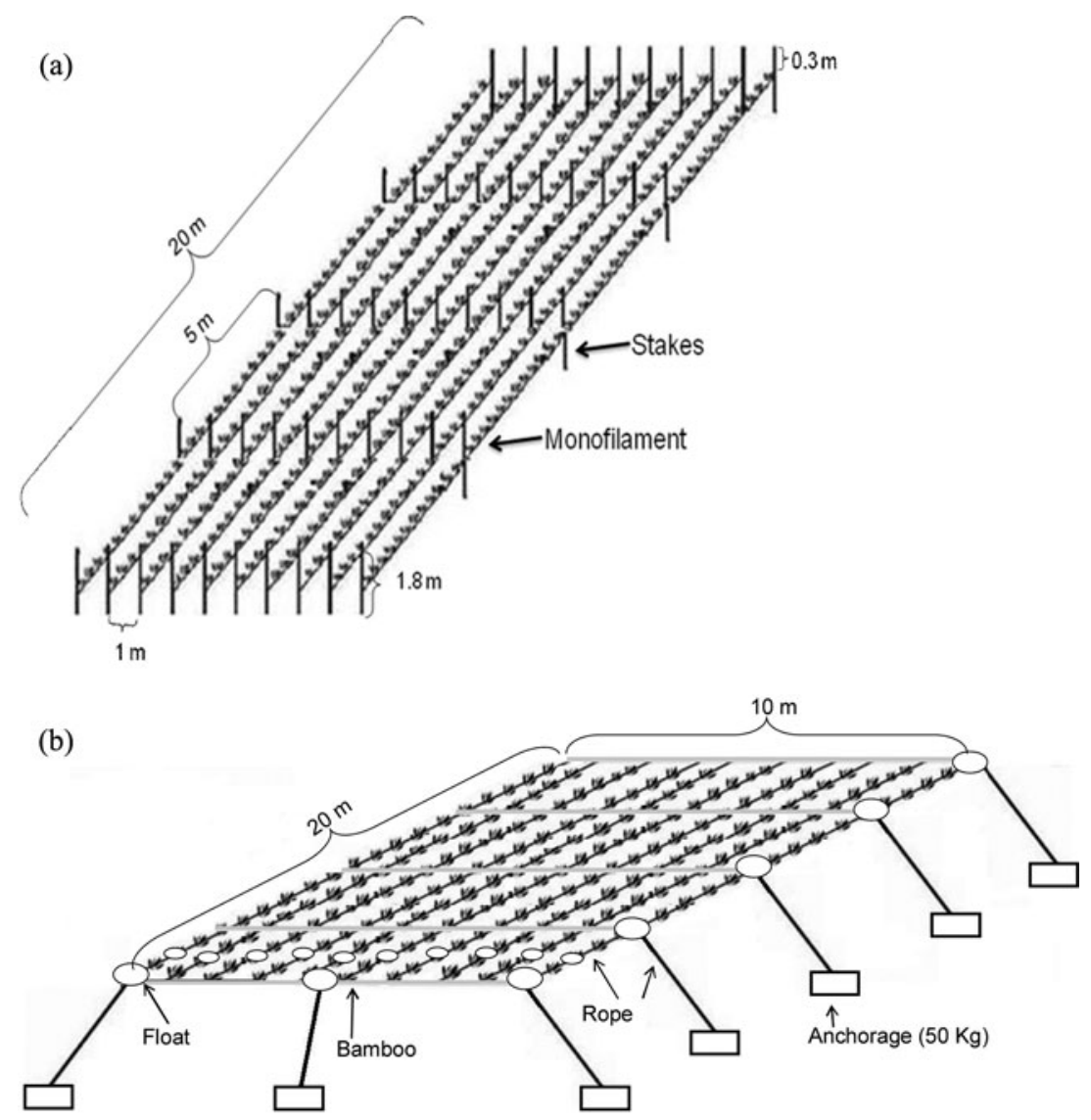

Source: Robledo et al. (2013).

FIGURE 1 Culture techniques used in seaweed farming: a) off-bottom method; b) floating system. The dimensions shown are for illustration purposes only and may vary in the field.

computed. The culture species in all systems is Kappaphycus alvarezii (with the exception of Tanzania where larger amounts of E. denticulatum are farmed, K. alvarezii is the predominant species around the world). To account for the contribution of unpaid family labor (which is used in many seaweed farms around the world), all systems assume the use of hired labor. The opportunity cost of family labor was computed in those cases for which data on labor costs were not available. The most important features of each system are discussed next.

\section{Indonesia}

The selected Indonesian farm consisted of a floating lines habitat system using sandbags as anchors and plastic bottles as floaters, with 
$30 \mathrm{~km}$ of planted lines. Eight 45-day cycles per year were assumed, resulting in an annual production of 33 tons of dry seaweed. The system was modeled after the "leader" farms (i.e., farms relying on hired labor as opposed to family labor) in the province of South Sulawesi (Neish, 2013).

\section{Philippines}

The selected Philippine system was a multiple raft long line farm (MRLL) occupying an area of $10 \times 50 \mathrm{~m}$ (around $2 \mathrm{~km}$ of planted lines). The MRLL is an innovative approach to seaweed farming used in areas with deep water ranges $(>5 \mathrm{~m})$ in Zamboanga Peninsula and Basilan (southern Philippines). Given the complexity of the farming structures, MRLL requires a substantially higher capital investment relative to the simpler fixed off-bottom method (Hurtado, 2013).

\section{Tanzania}

Two systems were considered for Tanzania: a $30 \times 10-\mathrm{m}$ off-bottom plot and a $27 \times 12-m$ floating lines habitat. Because seaweed die-offs tend to be avoided in the deeper floating-line system, it is assumed that eight production cycles per year are completed in the floating-line plot as compared to only seven in the off-bottom farm (i.e., a crop is lost in the latter system). The budgeted farm price for K. alvarezii of TZS 350 (USD 0.27 at 2009 exchange rates) per $\mathrm{kg}$ of dry seaweed is an approximate average of the prices received by independent farmers (i.e., not reliant on exporters/traders for the supply of culture materials) in Zanzibar. Dependent farmers normally receive lower prices (Msuya, 2013).

\section{India}

A floating system consisting of $453 \times 3 \mathrm{~m}$ rafts was considered for India. Production takes place during six 45-day cycles for a total of 270 production days per year (farms do not operate during the northeast monsoon, which lasts approximately 95 days). The system was modeled after the Self-Help Group (SHG) seaweed farms operating on the shores of Palk Bay, Tamil Nadu. SHGs are organized farmers' groups that may receive start-up government subsidies to support their agricultural activities. The modeled seaweed farm was assumed to operate without subsidies, nevertheless. Because SHGs rely heavily on family labor, an opportunity cost was computed based on the average wages earned by fishermen in the region (Krishnan \& Narayanakumar, 2013). 


\section{Solomon Islands}

The representative farm was modeled based on interviews with farmers in Wagina Island, South Choiseul province, a rural area with few livelihood alternatives besides seaweed farming. The operation assumes an annual yield of $21,700 \mathrm{~kg}$ using a floating system with $4 \mathrm{~km}$ of lines, with all labor being hired (Kronen, 2013).

\section{Mexico}

Off-bottom and floating-lines systems were modeled based on the results from experimental trials conducted by the Center for Research and Advanced Studies of the National Polytechnic Institute (CINVESTAV - Unidad Mérida, for its acronym in Spanish) in the community of Dzilam de Bravo, Yucatan (Muñoz et al., 2004). Each system consisted of $10 \times 20$-m modules scaled up to one hectare. Culture takes place during four two-month cultivation cycles as climatological conditions in Yucatan are unsuitable for farming during the late and early months of the year (Robledo et al., 2013).

\section{INVESTMENT COSTS}

Tables 1 through 6 present detailed investment costs for the eight farming systems. The scale of investment varied widely across systems, ranging from USD 42 for a $30 \times 10$-m off-bottom plot in Tanzania to USD 13,625 for a one-ha farm consisting of $10 \times 20$-m floating modules in Mexico. In terms of total farm investment, the systems could be ranked by country as Mexico $>$ Indonesia $>$ Solomon Islands $>$ Philippines $>$ India $>$ Tanzania. In terms of the total length of culture lines, the systems ranged from $270 \mathrm{~m}$ to $30 \mathrm{~km}$ and were ranked in the following order: Indonesia $>$ Mexico $>$ Solomon Islands $>$ India $>$ Philippines $>$ Tanzania (Table 7). Although farm infrastructure costs varied across systems, boats were often the most expensive item, particularly if they were equipped with outboard engines: in Solomon Islands, a 6.4-m fiberglass boat with outboard engine accounted for $97 \%$ of the total farm investment (Table 5). Ropes and stakes (the latter in off-bottom plots) were the other major investment items across systems.

An initial investment on propagules for the first production cycle was accounted for in the Indonesian, Philippine and Indian systems (Tables 1, 2 and 4). This cost was considered negligible in the Tanzanian and Solomon Islands systems. With the exception of Mexico, all systems assume that a portion of the harvested biomass in each cycle is set apart as planting biomass for the subsequent cycle. Propagules ( $100 \mathrm{~g}$ ) planted in each cycle are assumed to be purchased from a CINVESTAV phycology lab in the Mexican systems; this cost is therefore treated as an annual operating cost in Table $7 .{ }^{4}$ 
TABLE 1 Investment on Culture Lines, Infrastructure and Equipment for a 30-km Floating Lines Seaweed Farm in Indonesia, 2009

\begin{tabular}{|c|c|c|c|c|c|}
\hline Item & Units & Quantity & $\begin{array}{c}\text { USD/ } \\
\text { unit }\end{array}$ & $\begin{array}{c}\text { Total cost } \\
\text { (USD) }\end{array}$ & $\begin{array}{c}\text { Useful life } \\
\text { (Years) }\end{array}$ \\
\hline \multicolumn{6}{|l|}{ Investment per $\mathrm{km}$ of line } \\
\hline $1 \mathrm{~km}(13.6 \mathrm{~kg})$ of 5-mm PP line & $\mathrm{km}$ & 1 & 34.00 & 34.00 & 2 \\
\hline $0.2 \mathrm{~km}(11 \mathrm{~kg})$ of $10-\mathrm{mm}$ PP line & $\mathrm{km}$ & 0.2 & 136.00 & 27.20 & 2 \\
\hline $0.2 \mathrm{~km}(9 \mathrm{~kg})$ of $8-\mathrm{mm}$ PP line & $\mathrm{km}$ & 0.2 & 114.00 & 22.80 & 2 \\
\hline $1 \mathrm{~km}$ of $1-\mathrm{mm}$ PP line (for loops) & $\mathrm{km}$ & 1 & 1.00 & 1.00 & 2 \\
\hline Sandbag anchors & piece & 50 & 0.15 & 7.50 & 2 \\
\hline Plastic bottles as floats & piece & 500 & 0.03 & 15.00 & 2 \\
\hline Total investment for $1 \mathrm{~km}$ of line & & & & 107.50 & \\
\hline \multicolumn{6}{|l|}{ Farm equipment and facilities } \\
\hline 9-m canoe with 5.5-hp motor & unit & 2 & 500.00 & $1,000.00$ & 5 \\
\hline 6-m canoe with no motor & unit & 2 & 150.00 & 300.00 & 5 \\
\hline Miscellaneous tools and equipment & set & 2 & 150.00 & 300.00 & 5 \\
\hline Drying structures & set & 4 & 150.00 & 600.00 & 5 \\
\hline Shelters for shade & set & 2 & 800.00 & $1,600.00$ & 5 \\
\hline Sacks & pieces & 800 & 0.08 & 64.00 & 2 \\
\hline Total farm equipment and facilities & & & & $3,864.00$ & \\
\hline Propagules for initial planting & & & & 960.00 & 10 \\
\hline Total farm investment & & & & $8,049.00$ & \\
\hline
\end{tabular}

$\mathrm{PP}=$ Polypropylene.

Source: Neish (2013).

Despite the differences in the scale of operations, the total investment per $\mathrm{m}$ of line was approximately the same in Indonesia, Tanzania (floating), and India, at approximately USD $0.27 / \mathrm{m}$. The Philippine and off-bottom Mexican systems were also comparable (around USD $1.00 / \mathrm{m}$ ). The most economical investment corresponded to the off-bottom system in

TABLE 2 Investment on Culture Lines, Infrastructure and Equipment for a $10 \times 50$-m Multiple Raft Long Line Seaweed Farm (MRLL) in the Philippines, 2009

\begin{tabular}{|c|c|c|c|c|c|}
\hline Item & Units & Quantity & $\begin{array}{c}\text { USD/ } \\
\text { unit }\end{array}$ & $\begin{array}{l}\text { Total cost } \\
\text { (USD) }\end{array}$ & $\begin{array}{c}\text { Useful life } \\
\text { (Years) }\end{array}$ \\
\hline Motorized boat & unit & 1 & 526.32 & 526.32 & 5 \\
\hline Dug-out boat & unit & 1 & 120.00 & 120.00 & 3 \\
\hline Cultivation rope, flat binder & roll & 25 & 3.00 & 75.00 & 3 \\
\hline Anchor rope, polypropylene & roll & 3 & 78.58 & 235.75 & 5 \\
\hline Tying rope for floater, split flat binder & roll & 5 & 3.22 & 16.10 & 2 \\
\hline Iron bars & piece & 22 & 7.84 & 172.50 & 3 \\
\hline Floats & piece & 90 & 0.52 & 47.15 & 1 \\
\hline Whole bamboo & unit & 6 & 2.68 & 16.10 & 1 \\
\hline Fish net for drying, double width & roll & 1 & 9.20 & 9.20 & 3 \\
\hline Plastic strips - soft tie-tie & $\mathrm{kg}$ & 204 & 2.53 & 515.37 & 1 \\
\hline Total farm infrastructure & & & & $1,733.49$ & \\
\hline Propagules for initial planting & & & & 421.00 & 10 \\
\hline Total farm investment & & & & $2,154.49$ & \\
\hline
\end{tabular}

Source: Hurtado (2013). 
TABLE 3 Investment Costs for Off-bottom and Floating Seaweed Farming Systems in Zanzibar, Tanzania, 2009

\begin{tabular}{|c|c|c|c|c|c|}
\hline Item & Units & Quantity & USD/unit & Total cost (USD) & Useful life (Years) \\
\hline \multicolumn{6}{|c|}{$30 \times 10$-m off-bottom system } \\
\hline Ropes & $\mathrm{m}$ & 300 & 0.02 & 6.32 & 1 \\
\hline Tie-tie & roll & 10 & 0.21 & 2.08 & 1 \\
\hline Floaters & piece & 60 & 0.02 & 1.36 & 0.33 \\
\hline Skates (pegs) & piece & 60 & 0.02 & 1.14 & 0.50 \\
\hline Boat construction & unit & 1 & 5.62 & 5.62 & 10 \\
\hline Boat maintenance & unit & 1 & 0.07 & 0.07 & 1 \\
\hline Tarps & unit & 10 & 0.76 & 7.57 & 4 \\
\hline Drying rack frame & unit & 1 & 5.30 & 5.30 & 5 \\
\hline Palm fronds for rack & unit & 30 & 0.04 & 1.14 & 1 \\
\hline Storage containers & unit & 10 & 0.11 & 1.14 & 1 \\
\hline Diving masks & unit & 1 & 7.57 & 7.57 & 2 \\
\hline Knife & unit & 1 & 0.76 & 0.76 & 2 \\
\hline Machete & unit & 1 & 1.51 & 1.51 & 2 \\
\hline Total & & & & 41.57 & \\
\hline \multicolumn{6}{|c|}{$27 \times 12$-m floating lines system } \\
\hline \multicolumn{6}{|l|}{ Ropes for raft } \\
\hline $12 \mathrm{~mm}$ (frame line) & $\mathrm{m}$ & 1 & 14.01 & 14.01 & 10 \\
\hline $10 \mathrm{~mm}$ (anchor line) & $\mathrm{m}$ & 1 & 10.60 & 10.60 & 10 \\
\hline $8 \mathrm{~mm}$ & $\mathrm{~m}$ & 1 & 6.06 & 6.06 & 10 \\
\hline $4 \mathrm{~mm}$ (lines) & $\mathrm{m}$ & 3 & 1.89 & 5.68 & 1 \\
\hline Tie tie & roll & 11 & 0.21 & 2.29 & 1 \\
\hline Anchors (rocks) & unit & 16 & 0.15 & 2.42 & 4 \\
\hline Floaters (plastic bottles) & unit & 25 & 0.02 & 0.57 & 0.5 \\
\hline Knife & unit & 1 & 0.76 & 0.76 & 2 \\
\hline Machete & unit & 1 & 1.51 & 1.51 & 2 \\
\hline Frame construction & unit & 1 & 2.42 & 2.42 & 10 \\
\hline Boat construction & unit & 1 & 5.62 & 5.62 & 10 \\
\hline Boat maintenance & unit & 1 & 0.07 & 0.07 & 1 \\
\hline Tarps & unit & 10 & 0.76 & 7.57 & 4 \\
\hline Drying rack frame & unit & 1 & 5.30 & 5.30 & 5 \\
\hline Palm fronds for rack & unit & 30 & 0.04 & 1.14 & 1 \\
\hline Storage containers & unit & 10 & 0.11 & 1.14 & 1 \\
\hline Diving masks & unit & 1 & 7.57 & 7.57 & 2 \\
\hline Total & & & & 74.74 & \\
\hline
\end{tabular}

Source: Msuya (2013).

Tanzania (USD $0.15 / \mathrm{m}$ ), and the most expensive systems were found in Mexico (floating) and the Solomon Islands, at around USD $1.40 / \mathrm{m}$.

\section{COMPARATIVE ENTERPRISE BUDGETS}

Annual enterprise budgets for each system are presented in Table 7. Production in most cases takes place throughout the year with the exception of India and Mexico, which have shortened production seasons (less than 300 days a year) due to climatological factors. Annual productivity 
TABLE 4 Investment Costs for One Floating Raft $(3 \times 3 \mathrm{~m})$ for Seaweed Farming in Tamil Nadu, India

\begin{tabular}{|c|c|c|c|c|c|}
\hline Item & Units & Quantity & $\begin{array}{c}\text { USD/ } \\
\text { unit }\end{array}$ & $\begin{array}{l}\text { Total cost } \\
\text { (USD) }\end{array}$ & $\begin{array}{c}\text { Useful life } \\
\text { (Years) }\end{array}$ \\
\hline \multicolumn{6}{|l|}{ Farming system $(3 \times 3 \mathrm{~m} \mathrm{raft})$} \\
\hline Bamboo raft & foot & 64 & 0.07 & 4.36 & 2 \\
\hline Cornered anchors & $\mathrm{kg}$ & 1.50 & 0.87 & 1.30 & 2 \\
\hline Floats & set & 1.00 & 0.52 & 0.52 & $\overline{1}$ \\
\hline 3-mm nylon rope & $\mathrm{kg}$ & 0.45 & 2.39 & 1.07 & 2 \\
\hline 6-mm nylon rope & $\mathrm{kg}$ & 0.65 & 2.39 & 1.55 & 2 \\
\hline Ropes for seaweed cuttings & $\mathrm{kg}$ & 0.165 & 2.60 & 0.43 & 1 \\
\hline $3.5 \times 3.5 \mathrm{~m}$ nets (to prevent grazing) & $\mathrm{kg}$ & 1.13 & 1.63 & 1.84 & 1 \\
\hline $2-\mathrm{mm}$ ropes (to tie nets to raft bottoms) & $\mathrm{kg}$ & 0.09 & 2.39 & 0.21 & 2 \\
\hline Nylon rope (to tie rafts together) & $\mathrm{kg}$ & 0.10 & 2.39 & 0.24 & 2 \\
\hline $10-\mathrm{mm}$ anchor ropes & $\mathrm{kg}$ & 0.09 & 2.39 & 0.21 & 2 \\
\hline Mats, ladders, baskets, knives, etc. & set & 1 & 0.83 & 0.83 & 2 \\
\hline \multicolumn{6}{|l|}{ Propagules for initial planting } \\
\hline Propagules & $\mathrm{kg}$ & 60 & 0.04 & 2.17 & 10 \\
\hline Transportation & unit & 1 & 0.52 & 0.52 & 10 \\
\hline Total investment per raft & & & & 15.25 & \\
\hline Total farm investment (45 rafts) & & & & 686.25 & \\
\hline
\end{tabular}

Source: Krishnan \& Narayanakumar (2013).

of dry seaweed ranged from 1.10 (Indonesia) to 5.38 (Mexico) and 5.43 (Solomon Islands) $\mathrm{kg}$ per $\mathrm{m}$ of cultivation line. The high productivity achieved in the Mexican systems is remarkable given the shortened length (240 days) of the growout season. In addition to the favorable environmental conditions found in the Yucatan area, high growth rates can also be attributed to the use of large $(100 \mathrm{~g})$, high quality propagules. It should also be reminded that these productivity levels were achieved in experimental trials, which are assumed to be replicated at a commercial scale.

The relatively low productivity reported by the Indonesian farm may be influenced by the challenges associated with managing a large operation (30 km of culture lines); higher yields per $\mathrm{m}$ of line may therefore be easier to achieve in the smaller Tanzanian and Indian systems (between 2 and $3 \mathrm{~kg} / \mathrm{m} /$ year). Productivity is also relatively low in the Philippine raft system

TABLE 5 Investment Costs for a Floating Lines Seaweed Farm in Solomon Islands (4,000 m of Culture Lines)

\begin{tabular}{llrrrr}
\hline Item & Units & Quantity & $\begin{array}{r}\text { USD/ } \\
\text { unit }\end{array}$ & $\begin{array}{r}\text { Total cost } \\
\text { (USD) }\end{array}$ & $\begin{array}{r}\text { Useful life } \\
\text { (Years) }\end{array}$ \\
\hline $\begin{array}{lllrl}\text { 6.4-m fiberglass boat with outboard engine } \\
\text { Drying table }\end{array}$ & unit & 1 & $5,372.75$ & $5,372.75$ & 5 \\
$\begin{array}{l}\text { Ropes, netting, floaters, tools } \\
\text { Total }\end{array}$ & set & 1 & 160.92 & 160.92 & 5 \\
\end{tabular}

Source: Kronen (2013). 
TABLE 6 Investment Costs for One-ha Off-Bottom and Floating Seaweed Farming Systems in Yucatan, Mexico, 2009

\begin{tabular}{|c|c|c|c|c|c|}
\hline Item & Units & Quantity & $\begin{array}{c}\text { USD/ } \\
\text { unit }\end{array}$ & $\begin{array}{l}\text { Total cost } \\
\text { (USD) }\end{array}$ & $\begin{array}{c}\text { Useful life } \\
\text { (Years) }\end{array}$ \\
\hline \multicolumn{6}{|c|}{$10 \times 20$-m off-bottom modules scaled up to one ha } \\
\hline Stakes & set & 1 & $3,834.20$ & $3,834.20$ & 5 \\
\hline Monofilament & set & 1 & 481.87 & 481.87 & 5 \\
\hline Raffia and strings & set & 1 & 261.14 & 261.14 & 1 \\
\hline Protective netting & set & 1 & $3,070.15$ & $3,070.15$ & 5 \\
\hline Boat & unit & 1 & $1,036.27$ & $1,036.27$ & 5 \\
\hline $\begin{array}{l}\text { Land equipment (knives, crates, scales, } \\
\text { drying structures) }\end{array}$ & set & 1 & $1,641.56$ & $1,641.56$ & 5 \\
\hline Total & & & & $10,325.18$ & \\
\hline \multicolumn{6}{|c|}{$10 \times 20$-m floating modules scaled up to one ha } \\
\hline Polypropylene rope & set & 1 & $1,046.74$ & $1,046.74$ & 5 \\
\hline Raffia and strings & set & 1 & 261.14 & 261.14 & 1 \\
\hline Flotation buoys & set & 1 & $3,264.25$ & $3,264.25$ & 5 \\
\hline Weights & set & 1 & $2,932.29$ & $2,932.29$ & 5 \\
\hline Protective netting & set & 1 & $3,070.15$ & $3,070.15$ & 5 \\
\hline Bamboo & set & 1 & 373.06 & 373.06 & 5 \\
\hline Boat & unit & 1 & $1,036.27$ & $1,036.27$ & 5 \\
\hline $\begin{array}{l}\text { Land equipment (knives, crates, scales, } \\
\text { drying structures) }\end{array}$ & set & 1 & $1,641.56$ & $1,641.56$ & 5 \\
\hline Total & & & & $13,625.45$ & \\
\hline
\end{tabular}

Source: Robledo et al. (2013).

$(1.43 \mathrm{~kg} / \mathrm{m} /$ year$)$, which may reflect a larger impact of diseases such as ice-ice $^{5}$ in this country.

Average farm-gate prices varied widely across studies, from USD 0.27/ $\mathrm{kg}$ (Tanzania) to USD $1.09 / \mathrm{kg}$ (Philippines). As explained previously, distance to processing centers is the key factor influencing farm prices: the lowest prices were reported in the most remote producing regions (Tanzania and Solomon Islands) while seaweed produced in Indonesia, Philippines and Mexico fetched higher prices. It should be noted that Indian farmers reported relatively low prices (USD 0.33) despite the proximity of processing plants in Tamil Nadu and neighboring provinces.

Reflecting the labor-intensive nature of seaweed farming, labor accounted for the greatest share of variable costs across most budgets, normally representing around $50 \%$ of total costs of production. For illustration purposes, Tables 8 and 9 itemize labor activities and costs for the $30-\mathrm{km}$ floating farm in Indonesia and the $27 \times 12-\mathrm{m}$ floating farm in Tanzania. Total labor cost per $\mathrm{kg}$ of dry seaweed was lower in Tanzania (USD 0.03/ $\mathrm{kg}$ ) as compared to Indonesia (USD $0.13 / \mathrm{kg}$ ), which is to some degree expected given Tanzania's lower level of economic development. At around USD $0.18 / \mathrm{kg}$, labor costs per $\mathrm{kg}$ were similar in India, Solomon Islands and Mexico (Table 7). The highest labor cost was reported in the Philippines (USD $0.27 / \mathrm{kg}$ ). 


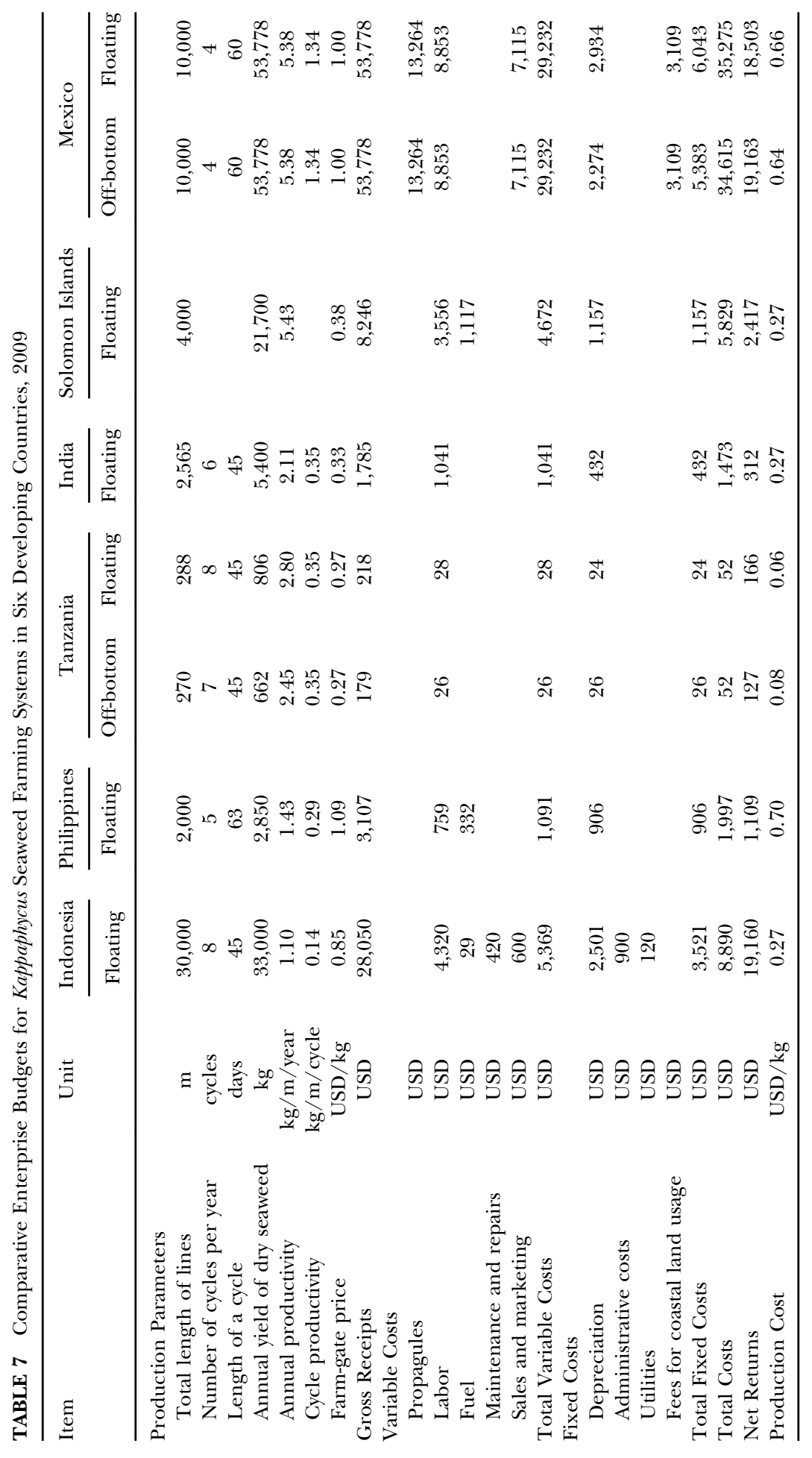


TABLE 8 Annual Labor Costs for a 30-km Floating Lines Seaweed Farm in Indonesia, 2009

\begin{tabular}{lcc}
\hline Item & USD/km/cycle & USD/km/year \\
\hline Attachment of propagules to lines & 6 & 48 \\
Placement of lines & 4 & 32 \\
Harvesting of lines & 4 & 32 \\
Drying of seaweed & 4 & 144 \\
Total cost per km & & 144 \\
Total cost per farm & & 4,320 \\
Total cost per kg of dry seaweed & & 0.13 \\
\hline
\end{tabular}

Source: Neish (2013).

Depreciation costs were computed based on the investment amounts and useful life of investment items listed in Tables 1 through 6, using the straight-line method. A useful life of 10 years was assumed for the initial investment on propagules reported in the Indonesian, Philippine and Indian systems. For simplicity and given that local conditions can vary widely, the enterprise budgets omit financial expenses (interest on operating capital and long-term loans).

Total production cost per $\mathrm{kg}$ of dry seaweed ranged from USD $0.06 / \mathrm{kg}$ in Tanzania (floating) to USD $0.70 / \mathrm{kg}$ in the Philippines (Table 7). Most systems achieved production costs below USD $0.30 / \mathrm{kg}$ with the exception of Mexico and the Philippines. Tanzania is the lowest-cost producer regardless of the production method; the floating farm is nevertheless the most profitable alternative as die-offs are minimized in this system. The relatively high costs in the Philippines were driven by its low productivity $(1.43 \mathrm{~kg} /$ $\mathrm{m} /$ year) whereas high costs in Mexico resulted from the purchases of propagules from an outside source. Despite a productivity of only $1.10 \mathrm{~kg} / \mathrm{m} /$ year, the Indonesian floating system had the largest profit margin (USD 0.58) due to the relatively high farm-gate prices. The lowest profit margin was computed for the Indian floating rafts (USD 0.06), which

TABLE 9 Annual Labor Costs for a 27×12-m Floating Lines Farm in Zanzibar, Tanzania, 2009

\begin{tabular}{lccrr}
\hline Activity & $\begin{array}{c}\text { Man hours } \\
\text { per cycle }\end{array}$ & $\begin{array}{c}\text { Wage } \\
\text { (USD/hour) }\end{array}$ & $\begin{array}{c}\text { Number of } \\
\text { cycles }\end{array}$ & $\begin{array}{c}\text { Total cost } \\
\text { (USD) }\end{array}$ \\
\hline Tying propagules & 32.00 & 0.03 & 8 & 7.27 \\
Planting & 2.00 & 0.03 & 8 & 0.45 \\
Farm management & 3.00 & 0.03 & 8 & 0.68 \\
Harvesting & 12.00 & 0.03 & 8 & 2.73 \\
Transporting seaweed to drying Location & 2.00 & 0.76 & 8 & 12.12 \\
Packing & 0.25 & 0.03 & 8 & 0.06 \\
Transportation to market & 0.50 & 0.23 & 8 & 0.91 \\
Tie-tie separation & 15.00 & 0.03 & 8 & 3.41 \\
Total cost & & & & 27.63 \\
Total cost per kg of dry seaweed & & & 0.03 \\
\hline
\end{tabular}

Source: Msuya (2013). 
resulted from the low farm-gate prices (USD 0.33) and the high opportunity cost of labor. The profit margin was also relatively low in the Solomon Islands (USD 0.11).

\section{Measuring Net Returns against International and National Poverty Lines}

The net returns listed in Table 7 can be interpreted as net returns to farm operator's labor and management, where the farm operator is understood to be the person responsible for the day-to-day management decisions in the farm (i.e., the farm owner). An instructive way to compare the economic performance of the farming systems in this study is to measure the level of net returns against an international benchmark of minimum welfare for households in developing countries. The international poverty line (IPL) as defined by the World Bank in 2008 (Ravallion et al., 2009), that is, USD 1.25 per capita per day at 2005 Purchasing Power Parity (PPP), was deemed an appropriate benchmark.

Figure 2 compares the annual net returns from the six floating systems in Table 7 to the annual IPL adjusted for a five-person household (USD 2,281 at 2005 PPP). Net returns (in 2009 current USD) were converted to USD at 2005 PPP (chained international dollars) using the chained PPP conversion factors provided by the Penn World Table, Version 8.0 (Feenstra et al., 2013). ${ }^{6}$ The goal of this analysis is to make a valid comparison among net returns to farm operator's labor and management in Table 7 in terms of the relative living standards afforded by these income levels across countries. The analysis assumes that the farm operator supports a five-person household using his income from the seaweed farm.

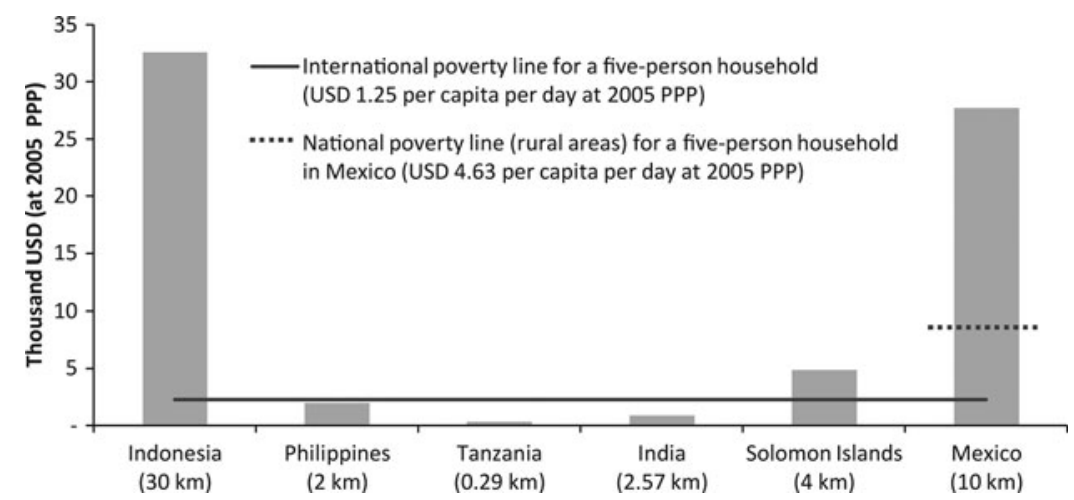

FIGURE 2 Annual net returns to operator's labor and management in six floating seaweed farming systems (USD at $2005 \mathrm{PPP}$ ). Total length of lines under cultivation is enclosed in parentheses next to the countries' names. The international poverty line and the Mexican national poverty line for five-person households are added for comparison purposes. 
A salient feature of Figure 2 is the large differences in economic performance across systems and relative to the IPL. Even disregarding the impact of farm-gate prices, it is clear that the scale of operations matter greatly. Despite its low productivity $(1.1 \mathrm{~kg} / \mathrm{m} /$ year $)$, the $30-\mathrm{km}$ Indonesian floating farm can potentially generate an annual income stream exceeding USD 30,000 (at $2005 \mathrm{PPP}$ ), which is nearly 16 times greater than the IPL. Boosted by its high productivity, the Mexican farm $(10 \mathrm{~km}$ of lines $)$ also generates a relatively high income (close to USD 30,000), exceeding the IPL by a factor of 12 . With $4 \mathrm{~km}$ of culture lines, the performance of the Solomon Islands farm is less impressive but still capable of delivering an income level in excess of the IPL (USD 4,862).

The smaller Philippine, Tanzanian and Indian systems fail to generate enough income to surpass the IPL. As explained before, the MRLL farm examined in the Philippines is a relatively expensive system to set up; the scale of operations should therefore be significantly greater than two $\mathrm{km}$ of lines in order to generate a substantial level of income. Because farm prices are relatively high in the Philippines, other lower-cost systems are bound to have an economic performance similar to the Indonesian systems, nevertheless. The Tanzanian and Indian farms are hampered by both the small scale of the operations and the low farm prices.

In addition to the IPL, most governments have also defined their own national poverty lines (NPLs). ${ }^{7}$ The NPLs of Indonesia, Philippines, Tanzania, India, and the Solomon Islands are in the vicinity of the IPL (USD 1.14, 1.73, 0.95, 1.37, and 1.87 per capita per day at 2005 PPP, respectively). ${ }^{8}$ Mexico is nevertheless a middle income country; at USD 4.63, its NPL is substantially higher than the IPL (CONEVAL, 2013). The Mexican NPL (for rural areas) is also shown in Figure 2 for comparison purposes. Clearly, the 10 -km floating farm generates sufficient revenue to bring a five-person household in rural Mexico over the higher NPL.

As explained previously, hired labor costs were assumed in the estimation of net returns in Table 7. A plausible alternative assumption is the reliance on family labor in the smaller Philippine, Tanzanian, and Indian systems. Figure 3 re-estimates net returns for these systems on the assumption that all labor is provided by members of the five-person household and not charged as an operating cost (these would be then net returns to household's labor and management). In this new scenario, the Philippine and Indian systems generate enough income (USD 3,323 and 3,377 at 2005 PPPs, respectively) to overcome their respective NPLs. In contrast, the net returns from the 288-m Tanzanian floating plot account for only $25 \%$ of the income needed to reach the lower Tanzania's NPL of USD 1,736 per household per year (USD 0.95 per capita per day). Income from this system would fail to reach the NPL even if farm prices were raised from USD 0.27 to USD $1.00 / \mathrm{kg}$ (current 2009 USD). 


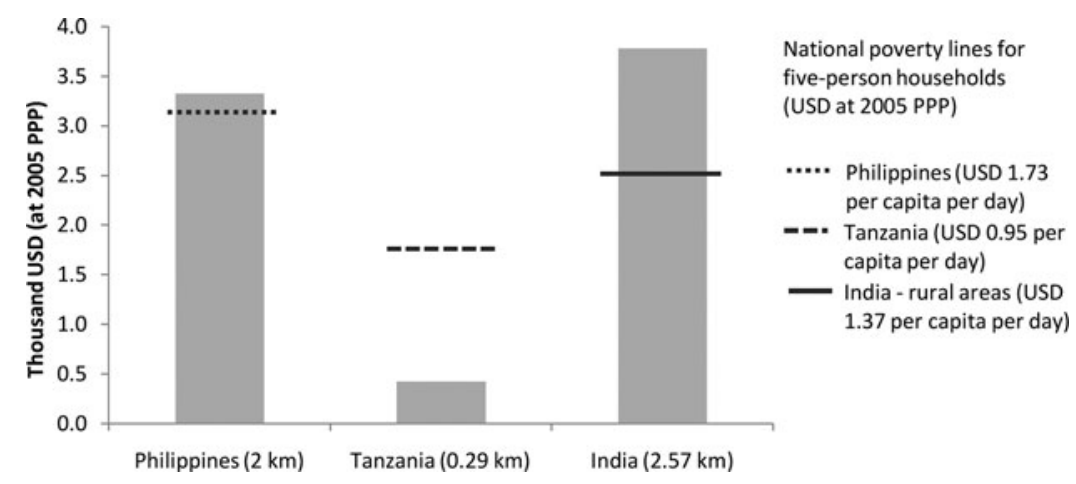

FIGURE 3 Annual net returns (USD at 2005 PPP) for floating seaweed farming systems in Philippines, Tanzania, and India relying on family labor. Total length of lines under cultivation is enclosed in parentheses next to the countries' names. National poverty lines are added for comparison purposes.

\section{Risk Analysis}

Given the large variability in seaweed prices that has been observed in recent years, a risk analysis was carried out to examine the impact of price fluctuations on the economic performance of the six floating farm scenarios presented in Table 7. Using the Excel add-on program Oracle Crystal Ball (Oracle Corporation, 2012), farm-gate prices were modeled as random variables following triangular distributions: likeliest values were those listed in Table 7 while prices $40 \%$ below and $40 \%$ above were used as minimum and maximum values, respectively. These intervals roughly approximate the range of price fluctuations observed over the last ten years (Valderrama et al., 2013). Table 10 summarizes the parameters of the triangular distributions for each farm scenario. Montecarlo simulations consisting of 1,000 trials were run for each case.

The resulting frequency distributions of annual net returns are displayed in Figure 4. The Philippine, Tanzanian, and Indian systems were assumed to rely on family labor while the cost of labor was accounted for in the other systems. As indicated in Table 10, the probability of losses was zero in all systems with the exception of the Solomon Islands and Mexico (3.8\% and $1.2 \%$, respectively): production costs in the latter two countries (USD 0.27 and $0.66 / \mathrm{kg}$, respectively) exceeded the minimum price assumed in the Montecarlo simulations (USD 0.23 and $0.60 / \mathrm{kg}$, respectively), giving rise to a small potential for losses.

National poverty lines for five-person households (dashed) were also added to Figure 4: the Indonesian floating farm was the only system capable of generating net returns exceeding its own NPL with $100 \%$ certainty. The risk of not reaching the NPL was also low in the Indian and Mexican systems (Table 10). In contrast, the Tanzanian farm failed to reach its NPL 
TABLE 10 Risk Analysis Measuring Sensitivity of Annual Net Returns (USD at 2005 PPP) to Variations in Farm-Gate Prices for Six Floating Seaweed Farming Systems

\begin{tabular}{|c|c|c|c|c|c|}
\hline & \multicolumn{3}{|c|}{$\begin{array}{l}\text { Parameters of triangular distributions for } \\
\text { farm-gate price (USD } / \mathrm{kg} \text { ) }\end{array}$} & \multicolumn{2}{|c|}{ Certainty levels (percent) } \\
\hline & Minimum & Likeliest & Maximum & $\begin{array}{l}\text { Probability of } \\
\text { losses }\end{array}$ & $\begin{array}{l}\text { Probability of not } \\
\text { reaching NPL }\end{array}$ \\
\hline Indonesia & 0.51 & 0.85 & 1.19 & 0.0 & 0.0 \\
\hline Philippines & 0.65 & 1.09 & 1.53 & 0.0 & 43.1 \\
\hline Tanzania & 0.16 & 0.27 & 0.38 & 0.0 & 100.0 \\
\hline India & 0.20 & 0.33 & 0.46 & 0.0 & 6.1 \\
\hline Solomon Islands & 0.23 & 0.38 & 0.53 & 3.8 & 30.8 \\
\hline Mexico & 0.60 & 1.00 & 1.40 & 1.2 & 7.6 \\
\hline
\end{tabular}

Triangular distributions were used to characterize variability in farm-gate prices: likeliest values were those listed in Table 7, while prices $40 \%$ below and $40 \%$ above were used as minimum and maximum values, respectively. The Philippine, Tanzanian, and Indian systems relied on family labor, while the cost of labor was accounted for in the other systems. Montecarlo simulations consisting of 1,000 trials were conducted in each case. NPL $=$ National Poverty Line.

even if prices are $40 \%$ above average (USD $0.38 / \mathrm{kg}$ ). Net returns in the Philippine and Solomon Islands systems also failed to reach NPLs when prices fell substantially below the average levels assumed in Table 7 .

\section{POLICY IMPLICATIONS}

With features such as low capital and operating requirements, short production cycles and a growing international market for carrageenan products, seaweed farming is a particularly appealing enterprise for inclusion into the integrated coastal management projects and fisheries management initiatives led by international development agencies, governments' fisheries departments, and NGOs in tropical developing countries (e.g., ACDI/VOCA, 2010; ADB, 2014; Blue Ventures, 2013; Conservation International, 2008; Sievanen et al., 2005). The dramatic increases in production in the Philippines and Indonesia since the late 1960s are frequently taken as evidence of the profitability of seaweed farming for households in coastal regions. An important lesson from this study, nevertheless, is that certain market and production conditions need to be satisfied for seaweed farming to fulfill its potential as a sustainable source of employment and livelihoods. In this regard, seaweed farming is no different from most other aquaculture enterprises with higher capital and technological requirements.

The first aspect to be discussed is farm prices. Low prices seriously hamper the revenue-generating potential of seaweed farming in the most remote producing regions (Tanzania, Solomon Islands). Reported prices in the Indonesian, Philippine and Mexican case studies ranged from 

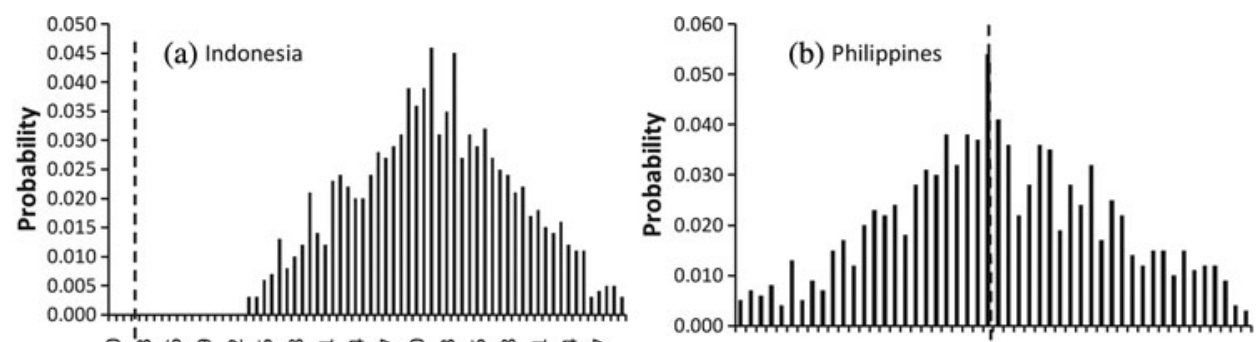

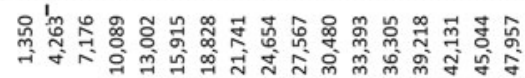

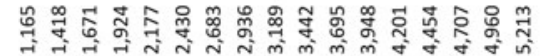
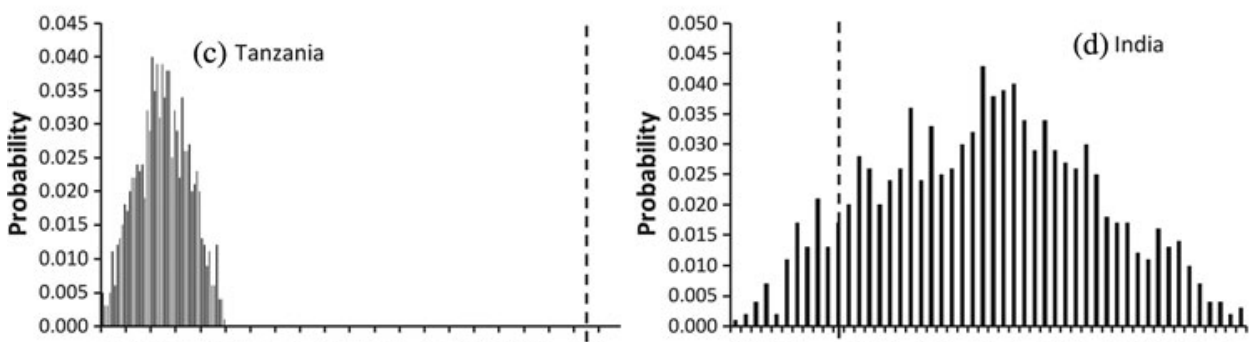

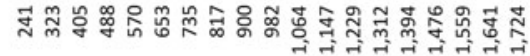
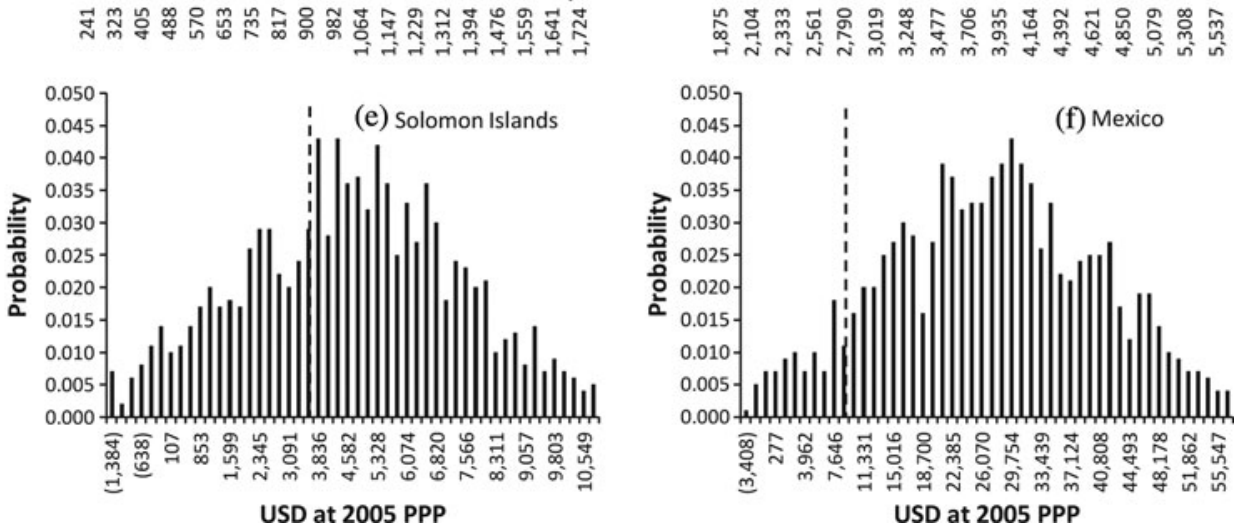

FIGURE 4 Risk analysis measuring sensitivity of annual net returns (USD at 2005 PPP) to variations in farm-gate prices for six floating seaweed farming systems. The Philippine, Tanzanian, and Indian systems relied on family labor while cost of labor was accounted for in the other systems. National poverty lines for five-person households (dashed) are added for comparison.

USD 0.60 through USD $1.40 / \mathrm{kg}$. In contrast, prices in Tanzania, India, and the Solomon Islands never exceeded USD $0.40 / \mathrm{kg}$. Low prices in Tanzania have led some farmers (mostly males) to quit seaweed farming altogether in recent years (Msuya, 2013).

As explained before, the problem of low prices is mostly one of reduced access to markets. The high shipping costs from the relatively remote farming locations in eastern Africa and the Pacific Islands constrain the ability of purchasers/exporters to offer the much higher prices received by Indonesian and Philippine farmers. The problem is compounded by the 
inability of some farmers to supply their own farming materials: in places such as Tanzania many farmers are highly dependent on processors/ traders for the sourcing of materials (stakes, culture lines, etc.). The cost of these materials is discounted from the price paid to farmers at the end of the production cycle. As long as farmers continue to depend on processors/traders for the procurement of their farming materials, their leverage to negotiate higher prices will be compromised. In this regard, microfinance could provide a viable means for dependent farmers to break free from disadvantageous arrangements with suppliers. Depending on the local context and given that the initial capital requirements are not very high, microloans might be available from credit institutions or through organizations such as Kiva.org. ${ }^{9}$ Seaweed farmers in the Philippines are already taking advantage of Kiva to raise investment capital to fund their operations (Kiva.org, 2012).

Diseases (ice-ice in particular) have had a severe impact on the farming of the higher-priced $K$. alvarezii in places such as Tanzania and the Philippines. Many farmers in Tanzania have turned to the farming of the more resistant Eucheuma denticulatum in an attempt to maintain farm yields but some have been discouraged by its lower price, normally around $50 \%$ of the price paid for $K$. alvarezii. Further research on disease-resistant strains of $K$. alvarezii and deep-water farming methods (which reduce the impact of diseases on $K$. alvarezii) is warranted. Some important steps in this direction have already been taken in Tanzania (Msuya et al., 2007).

Diminished economic returns resulting from low farm prices can also be enhanced by introducing value-added processes aimed at the production of seaweed-based soaps, lotions, powder, etc. In Tanzania, the Zanzibar Seaweed Cluster Initiative has been leading the efforts to create value-added seaweed products with some positive results (Msuya, 2011b).

The other aspect to consider is the scale of farming operations. The best performing system in this review was the $30-\mathrm{km}$ floating Indonesian farm despite its moderate productivity $(1.43 \mathrm{~kg} / \mathrm{m} /$ year $)$. The second-best performing operation was the second largest, the Mexican offbottom farm. Annual net returns were even higher in the Solomon Islands farm $(4 \mathrm{~km})$ than in the Philippine system $(2 \mathrm{~km})$ in spite of the much higher prices in the latter country (USD 1.09 vs USD 0.38). Although the Tanzanian systems were relatively productive $(2.45-2.80 \mathrm{~kg} / \mathrm{m} /$ year $)$, their reduced scale (less than $0.3 \mathrm{~km}$ ) precluded them from achieving income levels exceeding the NPL. The poor performance of these systems was of course compounded by the low farm prices. It is clear that family operations of this type are not sustainable in the long term, especially if seaweed farming is approached as the primary means of livelihood support.

Data from a four-year USAID project examining the viability of mariculture enterprises in Tanzania provide an indication of the minimum scale of 
operations needed to run a viable farm in this country (ACDI/VOCA, 2010). The technical project advised farmers to plant a minimum of 200 lines of $10 \mathrm{~m}$ each $(2,000 \mathrm{~m})$. After the initial $10-12$ weeks of farm expansion, an individual producer would be able to harvest $500 \mathrm{~kg}$ of dried seaweed per month $(3 \mathrm{~kg} / \mathrm{m} /$ year $)$. Assuming a price of USD 0.27 for $K$. alvarezii and a production cost of USD $0.06 / \mathrm{kg}$ (Table 7 ), net returns from this system would reach USD 1,260. At 2005 PPP, this would amount to USD 2,777, surpassing the NPL of USD 1,736 for a five-person household. This is of course a much more acceptable level of income than what is shown in Figures 2, 3 and 4. Other technical advisors recommend family farms in eastern Africa to handle at least three $\mathrm{km}$ of lines (de San, 2012).

Having farms to operate two or three $\mathrm{km}$ of seaweed lines may require a substantial increase in the managerial abilities of many family operations in eastern Africa. Nevertheless, it is essential that farmers as well governments' fisheries departments and international development agencies understand the importance of achieving these economies of scale prior to promoting seaweed farming as a sustainable livelihood activity in coastal areas. Scaling up acquires even more importance given the low seaweed prices prevailing in the region.

\section{CONCLUSIONS}

Standard budgeting techniques were used to develop comparative enterprise budgets for eight carrageenan seaweed farming systems in Indonesia, the Philippines, Tanzania, India, Solomon Islands and Mexico. The systems were selected to illustrate a variety of production and market scenarios currently found in seaweed farms around the world. The study reviewed small-scale, "village-based" operations in Tanzania; large-scale, "industrial" Indonesian farms, as well as intermediate systems in the Philippines, India, Solomon Islands, and Mexico.

In addition to the scale of operations and range of farming techniques, other biological and economic parameters varied significantly across systems. Productivity ranged from $1.10 \mathrm{~kg} / \mathrm{m} /$ year in the Indonesian floating farm to $5.43 \mathrm{~kg} / \mathrm{m} /$ year in the Solomon Islands operation. Farm prices were significantly higher ( $>$ USD $0.80 / \mathrm{kg}$ of dry seaweed) in Indonesia, the Philippines and Mexico due to their proximity to markets. At USD $0.06 / \mathrm{kg}$, Tanzania achieved the lowest cost of production while the highest costs per $\mathrm{kg}$ were computed for the Philippines (an MRLL system) and Mexico at USD 0.70 and USD 0.65 , respectively. Production costs for the other systems were around USD $0.27 / \mathrm{kg}$. Estimated production costs for Indonesia and the Philippines are not to be interpreted as representative costs given the large variety of farming systems and local production conditions found in these countries. 
Although seaweed farming is repeatedly portrayed as a coastal enterprise suitable for small-scale family farms, the analysis highlighted the importance of achieving economies of scale as indicated by the superior economic performance of the Indonesian "industrial-scale" farms relative to the family-run operations in Tanzania and India. In the case of Tanzania, the small 300-m farming plots generated a level of income that fell short from the international and national poverty lines.

Under conditions such as those described in the Tanzanian case, seaweed farming can still provide important socioeconomic benefits as a supplemental livelihood activity, but its impact will be limited. However, if the right market, production and environmental conditions are present, seaweed farming holds the potential to enhance substantially the socioeconomic wellbeing of coastal communities traditionally dependent on their surrounding marine resources. Assuming a farm price of at least USD $0.80 / \mathrm{kg}$, production costs of around USD $0.25 / \mathrm{kg}$, and a minimum of 2,000 $\mathrm{m}$ of production lines, seaweed farms can generate enough revenue to bring a five-family household over the national poverty line. This economic potential acquires even greater importance in places with few additional employment opportunities for coastal inhabitants. Even in underperforming regions such as Tanzania, seaweed farming has been instrumental in raising the socioeconomic status of female villagers, who traditionally have access to fewer employment alternatives than males.

\section{ACKNOWLEDGMENTS}

Acknowledgments are due to all seaweed farmers who contributed data for this study. All errors, omissions and views remain the sole responsibility of the authors.

\section{FUNDING}

The authors are indebted to the Food and Agriculture Organization of the United Nations for their financial support for this research.

\section{NOTES}

1. Seaweeds can be classified into three broad groups based on pigmentation: brown, red and green. Botanists refer to these broad groups as Phaeophyceae, Rhodophyceae and Chlorophyceae, respectively. Red and green seaweeds are usually smaller than brown seaweeds, ranging from a few $\mathrm{cm}$ to about a meter in length (McHugh, 2003).

2. Nori (Porphyra spp.) is another red seaweed with significant aquaculture production in East Asian countries but it is mainly used for direct human consumption. 
3. The international carrageenan industry is dominated by five or six multinational conglomerates, mainly based in the U.S. and Europe. China has also emerged in recent years as a major purchased of raw seaweed (McHugh, 2003; Tinne et al., 2006).

4. Unlike terrestrial plants, seaweeds do not propagate via seeds; they reproduce instead through a complex mechanism involving zoospores. The production of zoospores is not possible under laboratory conditions; tissue culture and micropropagation methods are thus the best alternatives for seedling production in labs. Although much research has been conducted in this area, lab production of seedlings is still not cost efficient from the point of view of farmers, most of whom rely on repeated vegetative propagation of harvested seaweed. Nevertheless, vegetative propagation does not augment genetic variability which may contribute to the decrease in growth rates and carrageenan yield and the increased susceptibility to diseases observed in some locations (Hurtado \& Cheney, 2003). Current research is aimed at optimizing culture conditions for the massive production of high-quality lab seedlings (Yong et al., 2014). If these efforts are successful, the industry could eventually turn away from repeated vegetative propagation and experience overall increases in productivity.

5. Ice-ice is caused when changes in salinity, ocean temperature, and light intensity inflict stress on seaweeds, making them produce a moist organic substance that attracts bacteria in the water and induces the characteristic whitening and hardening of the seaweed's tissues (McHugh, 2003).

6. Purchasing Power Parity (PPP) is a technique used to determine the relative value of different currencies. The PPP concept allows one to estimate what the exchange rate between two currencies would have to be in order for the exchange to be at par with the purchasing power of the two countries' currencies. This is the appropriate methodology to use when comparing living standards across countries and over time (Cheung, 2009).

7. In fact, the USD \$1.25 IPL is computed as the average of the national poverty lines of the poorest 15 countries for which data are available (Chen \& Ravallion, 2008).

8. The following were the sources consulted for the NPLs of Indonesia, Philippines, Tanzania, India, Solomon Islands, and Mexico, in respective order: Iriana et al. (2012); Philippine Statistics Authority (2014); Policy Forum (2012); Government of India (2013), SINSO/UNDP (2008), and CONEVAL (2013). The NPLs for the Solomon Islands (2008) and Mexico correspond to rural areas.

9. Kiva.org is a non-profit organization that allows people to lend money via the internet to people in developing countries through partner microfinance institutions.

\section{REFERENCES}

ACDI/VOCA (2010) Sustainable Environmental Management through Mariculture Activities. Final Quarterly Report and Final Report. ACDI/VOCA, Washington, DC, USA. Retrieved from http://pdf.usaid.gov/pdf_docs/PDACQ150.pdf

Arnold, S. (2008) Seaweed, power, and markets: a political ecology of the Caluya Islands, Philippines (Major paper). York University, Toronto, Ontario, Canada.

Asian Development Bank [ADB] (2014, May 30) Abalone and seaweed farming sustain better future for Filipino fishermen. Asian Development Bank, Manila, Philippines. Retrieved from http://www. adb.org/features/abalone-and-seaweed-farming-sustain-better-future-filipino-fishermen

Barta, P. (2008, October 21) Indonesia got soaked when the seaweed bubble burst. The Wall Street Journal. Retrieved from http://online.wsj.com/news/articles/SB122454073909251775

BBC News (2014, March 27) Seaweed - Zanzibar's 'gift from the ocean'. BBC News. Retrieved from http://www.bbc.com/news/world-africa-26770151

Beveridge, M., M. Phillips, P. Dugan, \& R. Brummett (2010) Barriers to aquaculture development as a pathway to poverty alleviation and food security: policy coherence and the roles and responsibilities of 
development agencies [PowerPoint slides]. OECD Workshop, Paris, 12-16 April 2010. Retrieved from http:/ / www.oecd.org/greengrowth/fisheries/45035203.pdf

Bindu, M.S. (2011) Empowerment of coastal communities in cultivation and processing of Kappaphycus alvarezii - a case study at Vizhinjam village, Kerala, India. Journal of Applied Phycology, 23(2), 157-163.

Bindu, M.S. \& I.A. Levine (2011) The commercial red seaweed Kappaphycus alvarezii- an overview on farming and environment. Journal of Applied Phycology, 23(4), 789-796.

Bixler, H.J. \& H. Porse (2011) A decade of change in the seaweed hydrocolloids industry. Journal of Applied Phycology, 23(3), 321-335.

Blanchetti-Revelli, L. (1995) Canadian misfortunes and Filipino fortunes: the invention of seaweed mariculture and the geographical reorganization of seaweed production. In P. McMichael (Ed.), Food and Agrarian Orders in the World Economy (pp. 97-112). Praeger Publishers, Westport, CT, USA.

Blue Ventures (2013). Community-based seaweed aquaculture: a sustainable alternative to fishing for southwest Madagascar. Retrieved from http://www.blueventures.org/conservation/ aquaculture.html

Chen, S. \& M. Ravallion (2008) The developing world is poorer than we thought, but no less successful in the fight against poverty. Policy Research Working Paper 4703. The World Bank, Washington, DC, USA. Retrieved from http://www-wds.worldbank.org/external/default/WDSContentServer/IW3P/IB/2010/01/21/000158349_20100121133109/Rendered/PDF/WPS4703.pdf

Cheung, Y.-W. (2009) Purchasing power parity. In The Princeton Encyclopedia of the World Economy. (Vol. 1, pp. 942). Princeton University Press, Princeton, New Jersey, USA.

Consejo Nacional de Evaluación de la Política de Desarrollo Social [CONEVAL] (2013) Informe de Pobreza en Mexico, 2012. Mexico, D.F., Mexico. Retrieved from http://www.coneval.gob.mx/ Informes/Pobreza/Informe\%20de\%20Pobreza\%20en\%20Mexico\%202012/Informe\%20de \%20pobreza\%20en\%20Mexico\%202012_131025.pdf

Conservation International (2008, November 26) Farming in the Seas. Retrieved from http://www. conservation.org/global/philippines/fmg/articles/Pages/FarmingintheSeas2.aspx

de San, M. (2012) The Farming of Seaweeds. Report SF/2012/28. Indian Ocean Commission/EU SmartFish Programme. Retrieved from http://commissionoceanindien.org/fileadmin/ projets/smartfish/Rapport/SF28.pdf

Espaldon, M.V.O., Z.M. Sumalde, C.M. Rebancos, J.D. Villanueva, \& M.T. Mercene-Mutia (2010) Sustainable livelihood and seaweed farming in Calatagan, Batangas, Philippines. IIFET 2010 Montpellier Proceedings. Retrieved from https://ir.library.oregonstate.edu/xmlui/bitstream/ handle/1957/38664/445.pdf?sequence=1

Feenstra, R.C., R. Inklaar \& M.P. Timmer (2013) Penn World Table, Version 8.0. Center for International Comparisons of Production, Income and Prices, University of Pennsylvania, Philadelphia, PA, USA. Retrieved from http://www.ggdc.net/pwt

Food and Agriculture Organization of the United Nations (2014) FishStatJ - Software for Fishery Statistical Time Series. Retrieved from http://www.fao.org/fishery/statistics/software/ fishstatj/en

Government of India (2013) Press Note on Poverty Estimates, 2011-12. Government of India, Planning Commission, New Delhi, India. Retrieved from http://planningcommission.nic. in/news/pre_pov2307.pdf

Gupta, M. (2010, September 24) Enhancing the contribution of aquaculture to poverty alleviation, food security and rural development. Global Conference on Aquaculture 2010 Podcasts. Food and Agriculture Organization of the United Nations, Thai Department of Fisheries, and Network of Aquaculture Centres in Asia-Pacific. Podcast retrieved from http://www. enaca.org/modules/podcast/soundtrack.php?soundtrack_id=43

Hayashi, L., C. Bulboa, P. Kradolfer, G. Soriano, \& D. Robledo (2014) Cultivation of red seaweeds: a Latin American perspective. Journal of Applied Phycology, 26, 719-727.

Hurtado, A.Q. (2013) Social and economic dimensions of carrageenan seaweed farming in the Philippines. In D. Valderrama, J. Cai, N. Hishamunda, \& N. Reidler (Eds.), Social and Economic Dimensions of Carrageenan Seaweed Farming (pp. 91-113). Fisheries and Aquaculture Technical Paper No. 580. FAO, Rome, Italy. 
Hurtado, A.Q. \& D.P. Cheney (2003) Propagule production of Eucheuma denticulatum (Burman) Collins et Harvey by tissue culture. Botanica Marina, 46(4), 338-341.

Iriana, N., A. Avenzora, \& J. Abidin (2012) Indonesia: poverty data governance [PowerPoint slides]. Effective Policies and Experiences for Poverty Reduction in Asia, Kunming, China. Retrieved from http://www.adbi.org/conf-seminar-papers/2012/12/10/5381.indonesia.poverty.data. gov/

Kiva.org. (2012) Gloria's loan page. Retrieved from http://www.kiva.org/lend/427486

Krishnan, M. \& R. Narayanakumar (2013) Social and economic dimensions of carrageenan seaweed farming in India. In D. Valderrama, J. Cai N. Hishamunda, \& N. Reidler (Eds.), Social and Economic Dimensions of Carrageenan Seaweed Farming (pp. 63-184). Fisheries and Aquaculture Technical Paper No. 580. FAO, Rome, Italy.

Kronen, M. (2013) Social and economic dimensions of carrageenan seaweed farming in Solomon Islands. In D. Valderrama, J. Cai, N. Hishamunda, \& N. Reidler (Eds.), Social and Economic Dimensions of Carrageenan Seaweed Farming (pp. 147-161). Fisheries and Aquaculture Technical Paper No. 580. FAO, Rome, Italy.

McHugh, D.J. (2002) Prospects for Seaweed Production in Developing Countries. FAO Fisheries Circular No. 968 FIIU/C968. Food and Agriculture Organization of the United Nations, Rome, Italy. Retrieved from http://www.fao.org/docrep/004/y3550e/y3550e00.HTM

McHugh, D.J. (2003) A Guide to the Seaweed Industry. FAO Fisheries Technical Paper No. 441. Food and Agriculture Organization of the United Nations, Rome, Italy.

Msuya, F.E. (2006) The impact of seaweed farming on the social and economic structure of seaweed farming communities in Zanzibar, Tanzania. In A.T. Critchley, M. Ohno, \& D.B. Largo (Eds.), World Seaweed Resources. ETI Information Services, Wokingham, UK.

Msuya, F.E. (2013) Social and economic dimensions of carrageenan seaweed farming in the United Republic of Tanzania. In D. Valderrama, J. Cai, N. Hishamunda, \& N. Reidler (Eds.), Social and Economic Dimensions of Carrageenan Seaweed Farming (pp. 115-146). Fisheries and Aquaculture Technical Paper No. 580. FAO, Rome, Italy.

Msuya, F.E. (2011a) The impact of seaweed farming on the socio-economic status of coastal communities in Zanzibar, Tanzania. World Aquaculture, 42(3), 45-49.

Msuya, F.E. (2011b) Zanzibar Seaweed Cluster Initiative [PowerPoint slides]. Cluster Initiative Presentations, 3rd PACF Conference, Entebbe, Uganda. Retrieved from http://www.pacfnetwork.org/pacf/wp-content/uploads/2013/09/Zanzibar-Seaweed-Cluster-Initiativen.pdf

Msuya, F.E., M.S. Shalli, K. Sullivan, B. Crawford, J. Tobey, and A.J. Mmochi (2007) A Comparative Economic Analysis of Two Seaweed Farming Methods in Tanzania. The Sustainable Coastal Communities and Ecosystems Program. Coastal Resources Center, University of Rhode Island and the Western Indian Ocean Marine Science Association. Retrieved from http://pdf.usaid. gov/pdf_docs/Pnadk663.pdf

Muñoz, J., Y. Freile-Pelegrín, \& D. Robledo (2004) Mariculture of Kappaphycus alvarezii (Rhodophyta, Solieriaceae) color strains in topical waters of Yucatán, México. Aquaculture, 30, 161-177.

My, Q. (2011) Poverty reduction from seaweed Kappaphycus alvarezii cultivation. VietFish International, 8(3), 70-72.

Namudu, M.T. \& T.D. Pickering (2006) Rapid survey technique using socio-economic indicators to assess the suitability of Pacific island rural communities for Kappaphycus seaweed farming development. Journal of Applied Phycology, 18(3-5), 241-249.

Naylor, J. (1976) Production, Trade and Utilization of Seaweeds and Seaweed Products. Fisheries Technical Paper No. 159. FAO, Rome, Italy.

Neish, I.C. (2013) Social and economic dimensions of carrageenan seaweed farming in Indonesia. In D. Valderrama, J. Cai, N. Hishamunda, \& N. Reidler (Eds.), Social and Economic Dimensions of Carrageenan Seaweed Farming (pp. 61-89). Fisheries and Aquaculture Technical Paper No. 580. FAO, Rome, Italy.

Oracle Corporation (2012) Oracle ${ }^{\circledR}$ Crystal Ball (Release 11.1.2.2) [Software]. Retrieved from http://www.oracle.com/us/products/applications/crystalball/overview/index.html

Pettersson-Löfquist, P. (1995) The development of open-water algae farming in Zanzibar: reflections on the socio-economic impact. Ambio, 24(7/8), 487-491. 
Philippine Statistics Authority (2014, April 29) Poverty incidence among Filipinos registered at 24.9\%, as of first semester of 2013. National Statistical Board, Republic of the Philippines. Retrieved from http://www.nscb.gov.ph/pressreleases/2014/PSA-NSCB-PR-201404-SS2-09_poverty incidence.asp

Policy Forum (2012) Growth in Tanzania: Is it Reducing Poverty? Policy Forum and Twaweza, Dar es Salaam, Tanzania. Retrieved from http://www.twaweza.org/uploads/files/Groth\%20in\% 20Tanzania_Policy\%20Forum.pdf

Ravallion, M., S. Chen, \& P. Sangraula (2009) Dollar a day. The World Bank Economic Review, 23(2), 163-184.

Robledo, D., E. Gasca-Leyva, \& J. Fraga (2013) Social and economic dimensions of carrageenan seaweed farming in Mexico. In D. Valderrama, J. Cai, N. Hishamunda, \& N. Reidler (Eds.), Social and Economic Dimensions of Carrageenan Seaweed Farming (pp. 185-204). Fisheries and Aquaculture Technical Paper No. 580. FAO, Rome, Italy.

Solomon Islands National Statistics Office/United Nations Development Program Pacific Centre [SINSO/UNDP] (2008) Solomon Islands: Analysis of the 2005/06 Household Income and Expenditure Survey. National Statistics Office, Department of Finance, Honiara, Solomon Islands. Retrieved from http://phtpacific.org/sites/default/files/surveys_dev_reports/90/files/ SLB_HIES-2005-06_AnalyticalReport_2008-07.pdf

Sievanen, L., B. Crawford, R. Pollnac, \& C. Lowe (2005) Weeding through assumptions of livelihood approaches in ICM: seaweed farming in the Philippines and Indonesia. Ocean $\mathcal{E}$ Coastal Management, 48(3-6), 297-313.

The Economist (2013, December 18) Farming the Alor islands: One man's weed. The Economist. Retrieved from http://www.economist.com/blogs/banyan/2013/12/farming-alor-islands

Tinne, M., G.L. Preston, \& G. Tiroba (2006) Development of seaweed marketing and licensing arrangements. Project ST 98/009: Commercialisation of Seaweed Production in the Solomon Islands. Technical Report 1. Gillet, Preston and Associates, Inc., Port Vila, Vanuatu. Retrieved from http://bluesquid.net/COSPSI/CoSPSI\%20Market\%20Licence\%20Report.pdf

Trono, G.C. (1990) Seaweed resources in the developing countries of Asia: production and socioeconomic implications. In I.J. Dogma, G.C. Trono, \& R.A. Tabbada (Eds.), Culture and Use of Algae in Southeast Asia: Proceedings of a Symposium on Culture and Utilization of Algae in Southeast Asia (pp. 1-8). Southeast Asia Fisheries Development Center, Tigbauan, Iloilo, Philippines.

Trono, G.C. (1993) Eucheuma and Kappaphycus: taxonomy and cultivation. In M. Ōno \& A.T. Critchley (Eds.), Seaweed Cultivation and Marine Ranching (pp. 75-88). Kanagawa International Fisheries Training Center, Japan International Cooperative Agency, Yokosuka, Japan.

Trono, G.C., H.R. Rabanal, \& I. Santika (1980) Seaweed Farming. FAO/UNDP South China Sea Fisheries Development and Coordinating Programme. SCS/80/WP/91. Manila, Philippines.

UN COMTRADE (2014) United Nations Commodity Trade Statistics Database. United Nations Statistics Division, New York, NY, USA. Retrieved from http://comtrade.un.org/db/ default.aspx

Valderrama, D., J. Cai, N. Hishamunda \& N. Ridler (Eds.). (2013) Social and Economic Dimensions of Carrageenan Seaweed Farming. Fisheries and Aquaculture Technical Paper No. 580. FAO, Rome, Italy.

Yong, W.T.L., S.H. Ting, Y.S. Yong, V.Y. Thien, S.H. Wong, W.L. Chin, K.F. Rodrigues, \& A. Anton (2014) Optimization of culture conditions for the direct regeneration of Kappaphycus alvarezii (Rhodophyta, Solieriaceae). Journal of Applied Phycology, 26, 1597-1606.

Zamroni, A. \& M. Yamao (2011) Coastal resource management: fishermen's perceptions of seaweed farming in Indonesia. World Academy of Science, Engineering and Technology, 60, 32-38. 